\title{
The Effect of Giving Breadfruit Leaf Flour (Artocarpus Altilis) on the Productivity of Laying Hens
}

\author{
Sri Lestari ${ }^{1, *}$, Yusnaini B. Telebe ${ }^{1}$, Yusri Sapsuha ${ }^{1}$ \\ ${ }^{I}$ Department Animals Husbandry, Agriculture Faculty, Khairun University, Ternate, Indonesia \\ ${ }^{*}$ Corresponden Author,e-mail: tari.kiss@yahoo.co.id
}

\begin{abstract}
Keywords: breadfruit leaves, performance, laying hens

\section{INTRODUCTION}

Laying hens are adult hens that are kept specifically for their eggs. The origin of laying hens is from the partridge which is dominated and selected so that it spawns quite a lot. The direction of the selection of jungle fowl is indicated by the many producers. However, because the partridge could have taken the eggs and meat, the direction of the selection had begun to be specific. Chickens selected for the purpose of meat production are known as broilers, while egg production is known as laying hens. In addition, the selection is also directed at the color of the eggshell until later known as white laying hens brown laying hens, laying hens have nervous properties (young surprised), slim body shape, white ear lobes, high egg production $200 \mathrm{eggs} / \mathrm{head} /$ year.
\end{abstract}

Laying hens are adult hens that are kept specifically for their eggs. The origin of laying hens is from the partridge which is dominated and selected so that it spawns quite a lot. The direction of selection of jungle fowl is indicated by the many producers. This study aims to determine the effect of breadfruit leaf flour (Artocarpus Altilis) in different rations on body weight gain, consumption and conversion of starter phase laying chicken rations in Jan Tabona Kelurahan, South Ternate, the method used was an experimental method using a Completely Randomized Design (CRD). The parameters observed in this study were performance of laying hens, ration consumption, body weight gain, feed conversion and egg physical quality. If there are significant differences between treatments will be followed by the Least Significant Difference Test (LSD).

The ration is an element that has an important influence on the production performance of laying hens. The ration is an arrangement of several poultry feeds in which must contain other nutrients as a whole, in quantity, time, and proportions that can meet all needs. Feed consumption is the number of rations the chicken eats during the maintenance period. Consumption is influenced by the shape, size, placement, and method of filling the ration. Based on the results of the phytochemical analysis, breadfruit leaves (Artocarpus Altilis) according to [1], contain a lot of flavonoids, tannins, and saponins, all of which can function as natural antioxidants. As a mega biodiversity country, breadfruit plants in Indonesia are easy to find because they are relatively evenly distributed, namely in Sumatra, Java, Kalimantan, Nusa Tenggara, Sulawesi, North Maluku, and Papua, so it is not difficult to find them. Abundant and abundant breadfruit leaves found in North Maluku have the potential to be used as feed additives for laying hens. Utilization of breadfruit leaves as animal feed because this plant contains a lot of antioxidants, is easy to obtain and does not compete with humans in its use.

According to [2] the active compound contained in breadfruit leaves (Artocarpus altilis) which is ethyl acetate fraction can bind calcium, the active compound comes from the flavonoid group. Calcium bound by flavonoids will form a calcium flavonoid bond through the calcium mechanism in kidney stones to form complex compounds with the -OH group of flavonoids to form Ca-flavonoids. This Caflavonoid bond which later becomes one of the sources of calcium to form the thickness of eggshell laying hens. Phytochemical content of antioxidants breadfruit leaves can be used to prevent free radicals and oxidative stress in various ways, including by making flour and mixing it with antioxidant rations in flavonoid compounds that can help to improve meat quality such as color, odor and reduce cholesterol levels [3].

Utilization of breadfruit leaves (Artocarpus altilis) in the ration can be used as an additional alternative feed material (feed additive) because it has substances that function as (precursors) to increase growth. In order to find out its effect, research on the administration of breadfruit leaves in rations on the productivity and quality of laying hens eggs.

This study aims to determine the effect of breadfruit leaf flour (Artocarpus altilis) in different rations on the productivity and quality of laying hens eggs. The benefits of this research are expected to provide scientific information to the public about the use of breadfruit leaves in laying hens as well as the benefits of breadfruit plants in improving the quality of eggs. 


\section{METHODS}

\section{A. Materials}

The equipment used in this study is a bucket, a ration container, a place to drink, a place to feed, cleaning equipment, stationery, machetes, plastic bags, scales and grinders/blenders, pens, notebooks. The materials used in this study include commercial feed, laying hens DOC, brown sugar, sawdust, breadfruit leaf flour.

\section{B. Research Materials}

\section{Experiment Cattle}

The cattle used in this study were 80 laying chicken starter stages aged 0-6 weeks.

\section{Ration}

The rations used in this study were commercial rations with the addition of breadfruit leaf flour

\section{Enclosure}

The cages used in this study were batrai cages with a length of $50 \mathrm{~cm} \times$ width $50 \mathrm{~cm} \times$ height $65 \mathrm{~cm}$ by 20 cages

\section{Research Implementation}

\section{Making Breadfruit Leaf Flour}

The process of making breadfruit leaf flour begins with selecting the green breadfruit leaves and then chopped until smooth and drying the breadfruit leaves with the help of sunlight until wilted (for a day) and dry then smoothed using a grinding tool (blender) until smooth and produce flour. The flour making process is carried out in the Animal Husbandry Study Program which coincides in Jan Tabona Kelurahan, South Ternate.

\section{Cage Preparation}

The cage is cleaned first, given a disinfectant and lime. On the exposed wall a tarpaulin curtain is installed to prevent the entry of wind into the cage.

\section{DOC preparation}

DOC which has just arrived, is allowed to stand for approximately one hour and then given a solution of brown sugar with the aim of reducing stress and weighing, then do the number installation. Livestock were divided into 20 cages randomly into replications. Feed and water are given ad libitum.

\section{Provision of food and drink}

The feed is given twice a day ie morning at 08.00 CET and afternoon at 16.00 CET. Drinking water is given ad libitum to the chicken. The amount of ration given is according to the standard required for the starter period laying hens. This research was carried out for 6 weeks until the chicken entered the starter period.

\section{Research Methods}

The method used is the experimental method using a completely randomized design (CRD). The treatment that was tried was the addition of breadfruit leaf flour, consisting of 5 treatments and 4 replications and concentration with the level:

$\mathrm{R} 0=$ commercial feed (Control)

$\mathrm{R} 1=2 \%$ breadfruit leaf flour $+98 \%$ commercial feed

$\mathrm{R} 2=4 \%$ breadfruit leaf flour + Commercial feed $96 \%$

$\mathrm{R} 3=6 \%$ breadfruit leaf flour $+94 \%$ commercial feed

$\mathrm{R} 4=8 \%$ breadfruit leaf flour $+92 \%$ commercial feed

\section{E. Research Parameters}

The parameters observed in this study were the performance of laying hens which included:

\section{a. Ration consumption}

Average ration consumption $(\mathrm{g})$ is calculated by the difference between the amount of ration given and the remaining amount of ration.

b. Increased body weight

$\mathrm{PBB}=$ Weight gain is calculated by way of initial body weight minus weekend body weight.

\section{c. Physical Quality of Eggs}

The physical quality of eggs includes: egg weight, albumen index (egg white), yolk index (egg yolk) and Haugh Unit (HU).

e. Depreciation of egg weight

Depreciation of egg weight is obtained from the initial weight difference by weight according to storage age or weight loss. The formulas used are :

Shrinkage weight $=\mathrm{Wo}-\mathrm{Wt}$

Note: $\quad$ Wo $=$ Initial weight of the egg $(\mathrm{g})$

$$
\mathrm{Wt}=\text { Weight of egg end }(\mathrm{g})
$$

\section{f. Haugh Unit Index (HU)}

$\mathrm{HU}$ calculation is a measurement of albumen height and egg weight. Eggs that have been weighed using a digital scale are broken, the egg fragments are placed on a flat glass then the height of the albumen is measured using a calipers. The formula of Haugh Unity which was made by Raymond Haugh namely:

$\mathrm{HU}=100 \log (\mathrm{H}+7.57-1.7 \mathrm{~W} 0.37)$

Information:

$\mathrm{HU}=$ Haugh Unit

$\mathrm{H}=$ Albumen Height

$\mathrm{W}=$ Egg Weight $(\mathrm{g})$

\section{g. Egg White Index (Albumen)}

The egg white index is a comparison between the height of the egg white with the average width and length of the egg white (Laily and Suhendra, 1979)

Egg White Index: T

Information:

$$
\mathrm{IPT}=(\mathrm{L} 1+\mathrm{L} 2) / 2)
$$

$\mathrm{T}=$ Egg White Height $(\mathrm{cm})$

L1 = Egg White Width $(\mathrm{cm})$

L2 = Egg White Length $(\mathrm{cm})$ 


\section{h. Yolk Index (yolk)}

The Yolk Index (IKT) is a ratio of the height of the yolk to the width of the yolk. The form of yolk is expressed by comparison between the height and width of the yolk expressed by the Yolk Index (YI).

The YI formula is $\mathrm{HYI}=\mathrm{Wd}$

Note:

$$
\begin{aligned}
& \mathrm{YI}=\text { Yolk index } \\
& \mathrm{H}=\text { Yolk Height }(\mathrm{cm}) \\
& \mathrm{Wd}=\text { Yolk Width }(\mathrm{cm})
\end{aligned}
$$

\section{RESULTS AND DISCUSSION}

\section{A. Effect of Breadfruit Leaf Flour on Ration Consumption}

Feed consumption is one of the factors that affect livestock productivity, where livestock can only live, develop and produce if they get a balanced nutritional intake in accordance with needs. The average consumption of starter phase laying hens by providing breadfruit leaf flour in rations aged 0-6 weeks is shown in Table 1 .

Table 1. Average Ration of Laying Hens Starter Phase 0-6 Weeks

\begin{tabular}{|c|c|c|c|c|c|}
\hline Deuteron & \multicolumn{5}{|c|}{ Treatment } \\
\cline { 2 - 6 } omy (g) & R0 & R1 & R2 & R3 & R4 \\
\hline 1 & 42,10 & 44,25 & 45,50 & 42,15 & 39,20 \\
\hline 2 & 42,25 & 42,50 & 45,00 & 41,00 & 40,35 \\
\hline 3 & 43,15 & 42,75 & 44,70 & 41,00 & 39,25 \\
\hline 4 & 43,35 & 43,35 & 44,00 & 43,50 & 40,30 \\
\hline Total & 170,85 & 172,85 & 179,20 & 167,65 & 159,10 \\
\hline Avarage & 42,71 & 43,21 & 44,80 & 41,91 & 39,76 \\
\hline
\end{tabular}

Different letters in the same line show real differences $(\mathrm{P}$ $<0.05)$ Based on Table 1 . The average consumption of laying hens for the starter stage phase of $0-6$ weeks of the study was R0 (42.71 g / head / day); R1 (43.21 g / head / day); R2 $44.80 \mathrm{~g} /$ head / day); R3 (41.91 g / head / day) and R4 (39.76 g / head / day). The highest average ration consumption was shown by treatment R2, namely the administration of breadfruit flour in ration by $4 \%$. Variance test results showed a significant difference ( $P$ $<0.05$ ) between treatments R0 and R1; R2; R3; and R4. The increased consumption of ration in $\mathrm{R} 2$ treatment, namely the administration of $4 \%$ breadfruit leaf flour in the ration due to the presence of flavonoids contained in breadfruit leaf flour. The active compound contained in breadfruit leaves (Artocarpus altilis) which is ethyl acetate fraction can bind calcium, the active compound comes from the flavonoid group [11]. Calcium bound by flavonoids will form a calcium flavonoid bond through the calcium mechanism in kidney stones to form complex compounds with the - $\mathrm{OH}$ group of flavonoids to form Caflavonoids. This causes absorption of $\mathrm{Ca}$ in the small intestine stimulates the parathyroid gland to secrete parathyroid hormone. The parathyroid hormone stimulates the hydrosilase system in the kidneys to produce hydroxicholecalciferol which results in the opening of $\mathrm{Ca}$ channels in the intestine so that absorption of $\mathrm{Ca}$ can be carried out. The results of absorption of $\mathrm{Ca}$ in the small intestine will be deposited into the bones and shells through the bloodstream. Increased calcium $(\mathrm{Ca})$ content in feed is very effective for increasing feed consumption so as to optimize egg production and egg weight [4].

Some factors that influence the consumption of rations are the health of chickens, the energy content in the ration, the type of food and the conditions of the ration given, the production needs and live chickens based on their growth rates and tastes and feeding methods used by farmers [5]. States that there are two main factors that influence the daily consumption of rations, namely the calorie content of the ration and the ambient temperature [6].

The increased consumption of rations in the $\mathrm{R} 2$ treatment gave effect to the increase in body weight and growth of laying hens in the starter period. This shows the fulfillment of nutrient requirements for livestock that are used for basic living, growth and production. Breadfruit leaves contain many mineral elements including calcium $(\mathrm{Ca})$. The addition of breadfruit leaf flour at the level of $4 \%$ can increase the absorption of nutrients, resulting in an increase in ration consumption followed by an increase in chicken body weight. States that the concentration of minerals in the ration can be increased to anticipate the reduction in ration consumption at high ambient temperatures [7]. This means that the addition of $4 \%$ breadfruit leaf flour in the mineral content of the ration also increased.

\section{B. The Effect of Breadfruit Leaf Flour on Increasing Weight of Laying Chicks for Starter Phase}

Weight gain is the difference between the final body weight and the initial body weight during the maintenance period. Weight gain is a reflection of the growth of cells / tissues in the body. The average weight gain for laying hens phase is shown in Table 2 .

Table 2. Average Increased Weight of Laying Hens Starter Phase Age 0-6 Weeks

\begin{tabular}{|c|c|c|c|c|c|}
\hline $\begin{array}{c}\text { Deuterono } \\
\text { my (g) }\end{array}$ & \multicolumn{5}{|c|}{ Treatment } \\
\cline { 2 - 6 } & R0 & R1 & R2 & R3 & R4 \\
\hline 1 & 85,35 & 85,80 & 86,75 & 83,15 & 81,45 \\
\hline 2 & 84,50 & 85,25 & 86,80 & 85,10 & 82,50 \\
\hline 3 & 84,70 & 85,70 & 87,25 & 83,25 & 80,65 \\
\hline 4 & 84,55 & 86,00 & 87,65 & 83,45 & 81,50 \\
\hline Total & 339,10 & 342,75 & 348,45 & 334,95 & 326,10 \\
\hline Avarage & 84,78 & 85,69 & 87,11 & 83,74 & 81,52 \\
\hline
\end{tabular}

Based on Table 2. The average weight gain for laying hens for the starter phase aged 0-6 weeks of the study was R0 (84.78 grams); R1 (85.69 grams); R2 (87.11 grams); R3 (83.74); and R4 (81.52 grams). The highest average weight gain in giving $\mathrm{R} 2$ is breadfruit leaf flour in a ratio of $4 \%$. The Variance Test showed a significant difference ( $P$ $<0.05$ ) between treatments R0 and R1; R2; R3; and R4. The results showed that the higher percentage of breadfruit leaf addition in the ration could have a significant effect, namely a decrease in body weight growth and also affect 
the consumption and conversion of the ration. This is in line with the opinion of [8] which states that rapid growth is supported by increased consumption of rations.

The provision of breadfruit leaf flour in rations up to $8 \%$ affects the consumption of rations, this shows that the tannin contained in breadfruit leaf flour can reduce the palatablity ration, so that the consumption of rations and body weight gain is also reduced. High tannin content in the ration produces a pungent odor so that the ration given is less like by poultry $[12,13]$.

The ration is declared good if it is able to meet all nutritional needs appropriately, both the type, amount, and nutritional supplements for livestock needs. Increasing the weight of laying hens can achieve maximum results, there are several factors that must be considered, namely good seedlings, ambient temperature, adequate preparation of rations and cages in addition to the rations consumed will greatly determine the increase in chicken body weight during growth and increase is still influenced by food substances in the ration given [6].

\section{Effect of giving Breadfruit Leaf Flour on rations Conversion for the Beginning Phase of Laying Chicks}

Rations conversion is a ratio of rations or comparingspent by rations chickens with live weight for a certain period of time. The smaller the conversion rate the better the efficiency of ration use. The avarage of conversion starter laying chicken ration by giving breadfruit leaf flour are listed in Table 3.

Table 3. Average Rations Chicken laying eggs early stage at 0-6 Weeks

\begin{tabular}{|c|c|c|c|c|c|}
\hline $\begin{array}{c}\text { Deuteronomy } \\
(\mathbf{g})\end{array}$ & \multicolumn{5}{|c|}{ Treatment } \\
\cline { 2 - 6 } & $\mathbf{R 0}$ & $\mathbf{R 1}$ & $\mathbf{R 2}$ & $\mathbf{R 3}$ & $\mathbf{R 4}$ \\
\hline 1 & 0,49 & 0,52 & 0,52 & 0,51 & 0,48 \\
\hline 2 & 0,50 & 0,50 & 0,52 & 0,48 & 0,50 \\
\hline 3 & 0,51 & 0,50 & 0,51 & 0,49 & 0,49 \\
\hline 4 & 0,51 & 0,50 & 0,50 & 0,52 & 0,49 \\
\hline Total & 2,01 & 2,02 & 2,05 & 2,00 & 1,96 \\
\hline Avarage & 0,50 & 0,51 & 0,51 & 0,50 & 0,49 \\
\hline
\end{tabular}

Based on Table 3. The average conversion of starter phase feed ration by breadfruit leaf flour is R0 (0.50); R1 (0.51); R2 (0.51); R3 (0.50) and R4 (0.49). The average ratio obtained in this study is on average still at an appropriate level for the average period of laying hens. However, R4 which provides $8 \%$ of the leaf meal, shows the lowest feed conversion. The higher the breadfruit, the higher the level of deliciousness. The tannin content in breadfruit leaves causes low digestibility so that it can reduce the ratio of consumption and growth which is relatively stunted. In line with the opinion of states that the palatability of rations is very much below the shape, odor, and texture of the ration given. Provision of up to $8 \%$ leaf flour in laying hens causes the smell of tannins from these rations to sting so that cattle do not like them.

Tannins can form complex bonds with proteins, starches, cellulose, and minerals. Tannins can affect the nutritional value of food and feed consumed by animals found in legume plants, grasses, and that ripe fruit. Tannins cause wrinkles on the tongue because it can bind with salivary fluid in the mouth [9].

The tannin content of $0.5-2 \%$ in poultry feed causes harmful effects on growth and egg production, while at the level of $3-7 \%$ it can cause death [9]. Based on research conducted by [10] decreased consumption that occurred in rations containing tannins by $2.71-3.54 \%$. Tanin by $2.76 \%$ caused a decrease in consumption by $19.4 \%$. According to, feeding containing tannins by $0.33 \%$ is not suitable for poultry, especially for chickens. When giving tannin content reaches $0.5 \%$ or more it inhibits the growth of chickens because tannins fight nitrogen retention and decrease power, the required amino acids can be absorbed by intestinal villi which are used for growth and development of body tissues.

Feed conversion is also useful for measuring livestock productivity because feed conversion is a comparison between the ration consumed and the resulting weight gain. The higher the value of ration conversion indicates the more ration needed to increase body weight per unit weight and the lower the value of ration conversion means the quality of ration is getting better $[14,15]$.

More and more a low conversion to ration, it means livestock is more efficient in using rations. Factors affecting ration conversion are growth speed, the energy content in the ration, the fulfillment of nutrients in the ration, environmental temperature and health of the poultry $[16$.

\section{CONCLUSION}

Conclusion should be written briefly, answer the aims or hypothesis of the research, do not repeat the discussion. Conclusion written critically, logically and honestly based on the existing fact, and full of cautions if there is a generalization. The conclusion is written in one paragraph form, without numbering or bullets.

\section{REFERENCES}

[1] Siddesha, M. J., Angaswamy, N., and Vishwanath, B.S., 2011. Phytochemical Screening and Evaluation of Inhibitory Activity of Angiotensin Conversion Conversion from Artocarpus altilis Leaf. Research on Natural Products 25 (20): 1931-1940.

[2] Jatmiko, S. 2013. The Effects of Ethyl Acetate Fraction of Breadfruit Leaves (Artocarpus Altilis Park Fosberg.) On Calcium Urine Levels of Male Mouse Sprague Dawley Strain Sprague Dawley Strain In Vivo. Journal of Pharmacy Study Program STIKES Ngudi Waluyo. STIKES Ngudi Waluyo. Semarang.

[3] Guyton, A.C. 1997. Human Physiology and Disease Mechanisms (Human Physiology and Disease Mechanisms). (Terj.) Petrus Andriyanto. Jakarta: EGC. p. 665-708.

[4] Oderkirk, A. 2001. The Role of Calcium Phosphorus and Vitamin D3 in Egg Shells and 
Bone Formation. Nova Scotia Department of Agriculture and Marketing. www. Poultrynet.com. Accessed February 11, 2018.

[5] Rasyaf, M. 1991. Management of Egg Production. Second Edition. Kanisius. Yogyakarta.

[6] Amrullah, I.K. 2004. Laying Chicken Nutrition. Matter III. One Mountain Budi Institute. Bogor.

[7] Balnave D. 1995. Nutrition of Broilers and Laying Hens at High Temperature. Proceedings of the Scientific Meeting of Animal Husbandry Research Results (Balitnak Ciawi Bogor).

[8] Hermana. W.W.G. Palliang, L. Sofyan, N. Sold. 2012. The Effect of Use of Silaleikan Flour in the Ration Against the Appearance of Aksas Broilers. IPB. Bogor.

[9] Cannas, A. 2008. Tanin. www.cornelluniversity.edu/Cornellpoisonplant / ToxicAgents / Tannin /. html [April 2, 2008].

[10] Ambula, M. K., G. W. Oduho and J. K. Tuitoek. 2001. Effects of sorghum tannins, tannin binders (polyvinylpyrrolidone) and sorghum inclusion rates on the performance of broiler chicks. AsiaAus. J. Anim Sci. (14) 9: 1276-12.

[11] Orhan D. D., Berrin özc-elik, Selda özgen, F. Ergun. 2010. Antibacterial, antifungal, and antiviral activity of some flavonoids. Microbiological Research, 165: 496-504

[12] Lacin, E., A. Yildiz, N. Esenbuga, M. Macit. 2008. Effect of differences in initial group weight on egg laying performance and quality parameters of Lohman laying eggs. Czech J. Anim. Sci 53 (11): 466-471.

[13] Bihan-Duval, E. L., C. Berri, E. Baeza, N. Millet \& C. Beaumont, 2001. Estimation of genetic parameters of meat characteristics and their genetic correlations with growth and body composition in experimental broiler lines. Little birds. Sci 80: 839-843/

[14] Hudson, B. P., R. J. Lien, and J. B. Hess. 2001. Effects of weight uniformity and pre-peak feeding programs on the performance of broiler hens. J. Appl. Poultry Res. 10: 24-32.

[15] In Masso, R. J., A. M. Dottavio, Z. E. Canet and M. T. Font. 1998. Dynamic body weight and egg weight in layers. Little birds. Sci 77: 791-796.

[16] Indonesian National Standard (SNI) No. 01-39272006. Quality Requirements for Starter Phase Laying Chicken Ration. 